\title{
The Relationship between Social Status and Sports
}

\author{
Hikmet TURKAY ${ }^{1, *}$, A. Azmi YETIMM ${ }^{2}$ \\ ${ }^{I}$ Kafkas University, High School of Physical Education and Sports. Kars, Turkey \\ ${ }^{2}$ Gazi University, Faculty of Sport Sciences. Ankara, Turkey
}

*Corresponding Author: Hikmet TURKAY, Kafkas University, High School of Physical Education and Sports. Kars, Turkey

\begin{abstract}
The purpose of this study is to examine social status and sports relations. For this reason, the related literature has been examined and discussed under some titles. These are; concept of social status and sports, social aspect of sports and sports as status determiner. As a result; social status is determined by the social values in a society and it is seen as a status determiner in sports as well as many social status indicators as status determinants in present-day societies. The strength of the socio-cultural aspects of sports and the high level of interest, which is social perception and sports, have brought to the forefront the relation of sport to social status. In the beginning, the individual sports activities began to gain social qualities and became an important tool in socialization after reaching large masses and with this aspect they started to enter into the values that give status to the individuals in the society.
\end{abstract}

Keywords: Social Status, Sports, Socializing.

\section{INTRODUCTION}

Society is defined as "a structure consists of people that have developed a common life culture in a specific region, people that formed common denominators of history, culture, and mentality and feel that they belong in there" (Zahra, 2015). Society is not a casual, random combination of people, but a regular combination of self-composed parts. As part of this structure, the individual has a "place" in the society he/she lives in, and this shows his/her status in society.

Status is a social classification tool which we use the first time we meet with other individuals in social life and utter as a part of our identity when asked to identify ourselves (Demir, 2016). When approached in small perspective, the status indicates the formal or professional position (married, captain etc.) of an individual in a group; but in a larger perspective, the status indicates the importance of an individual in the world (Lembet, 2014).

Status is determined by the values that are valid in that society. These values are gender, family, educational status, success, and wealth. In some societies, the family of the individual; in some societies, the educational status of the individual; in some societies, the personal success of the individual and in some societies the wealth of the individual is an indicator of status (Bilgin, 1991). In 2004, the successful person meant an individual from any race who gained money, power, and fame in countless branches in the commercial world not by heritage but with their own activities in London, New York, Los Angeles and Sydney. Sports, science, and arts are at the top of these branches (Botton, 2005).

Society sorts these values by their importance by looking at their political, economic, scientific and sometimes sportive and artistic functions. While categorizing status indicators, sports should also be included within these values because it is the society that determines status. Therefore, the importance given to the sports and perception of the sports by the society makes the sports a status determiner social value.

Growing importance of the sports within the community also increased its social status and provided successful athletes a valued, imitated and prestigious position in almost every society. At the same time, sportsmanship is evaluated within earned status whether it is done as a profession or for other 
purposes. In this study; status indicator sports have been discussed and the relationship between socialization and status of sports is tried to be explained by scanning related literature.

\section{Social Status}

The origin of the word status comes from Latin "statum" verb meaning "standing". Status expresses the position of an individual in society. Individuals that are living in a society have a particular place and position. This place and position are called status. Status can be described as the place of the individual in the reputation and place ranking that determines the social state of the individual (Odabaş1, 2006). Indeed, almost every individual care about being appreciated and respected by others in society (Eder, 1985).

Sociologist Linton is first to describe status for Sociology. Linton said that status represents the position of an individual related to the entire society and it is only a total of rights and duties apart from the individual that holds it. Because these rights and duties can only be described in relationships between the individuals; it is rather difficult to perpetuate the discrimination between statuses and the individual that experiences the rights and duties formed by statuses (Chin, 2011).

In the studies about social status, popularity and prestige; there have been conceptional rankings in terms of the social perception of social status (Vaillancourt \& Hymel, 2006). According to Max Weber, it is the respect aspect of social stratification and it follows a certain respectable way of life in society (Kerbo, 2000). As a matter of fact, Lipset, who adopts a certain part of Weber's status analysis, explains status as positive or negative honorific evaluation or reputation of individuals or locations (Turner, 2000).

Botton likens status to a key that unlocks the door of unique wealth. Because the status inoculates a certain sense of trust to the individual and determines which behavior of an individual will see approval and liking of the others and what will satisfy them (Bilgin, 1991). In Warner's society studies, status is often a notion equated with personal dignity rather than social obligations, duties, and rights (Parsons, 1970). In such studies, it can be determined whether the behavioral differences observed relating to status are a cause or a consequence of status of the individuals (Coie \& Kupersmidt, 1983).

\subsection{Status Types}

Social scientists who have studied how a person has social status in society have analyzed the origins of the social status and found that social status is determined in one of two main constituents: Attributed and earned status.

In attributed status, there is nothing an individual can do about his/her status and there are criteria that the society applies to the individual. The most obvious example of this is the genealogical criteria. In an Italian or Irish family, the person has no choice to be black or white and these characteristics which are beyond the person's power are discussed under the attributed status. In earned status, consequences of the social efforts of individual are evaluated and this success runs in both directions. For example, a brilliant doctor does not only contribute to his prestige by his own working but also gives honor and respect to the profession. Despite the individual has more than one status, the most dominant status is called "key status" and society members generally recognize each other by these statuses (Fichter, 2015).

Status does not express society's positioning or assigning meaning and value to its own members and individuals' thoughts about themselves but expresses society's thoughts about them. Status is honor or dignity that are ascribed to an individual or a group by other members of the society. Therefore, status is expressed as the society's perception and understanding of an individual or a group that is a member of the society (Giddens, 2000).

Unlike other ethnic origins in America, black people did not benefit from the educational and professional acquisitions for many years. This also shows that status criteria are formed by ethnic origin as well as respect, dignity and professional prestige (Karayaka, 2006). In addition, according to the social perception, the status transfer should be taken into account in terms of prestige and profession. For example, a team coach can have high personal popularity by his or her intelligence, personality and knowledge but this person gained his dignity by the position he holds so the status of the position is transferred to the person. 
While status is a condition of the society rather than individual's oneself; this aspect of the status comes to the forefront in Fitcher's definition and status is a position or a place that the people around an individual consider appropriate for the individual. Therefore, the structure of the society in which the individual lives gains importance and the functions that have primary importance in society are elements taken into account in the transfer of status (Simsek, 2010).

\subsection{Factors that Determine Status}

Status is a social evaluation output (Sencer, 1967). Nonetheless, there are few behavioral patterns and criteria that can help identify the status of the individuals (Dodge, 1983). The concept of achieved status in the modern society began to develop while the origins of social stratification were linked to ascribed status in pre-industrial primitive societies (Kalaycığlu et al., 2010). When we want to describe status order by following Weber; it is seen as a structure that reflects the personal characteristics of the individual, perceptions, and dignity of the community (Chan, 2010).

Throughout the history, societies' perspective to the high status and the groups that the society thought they were worthy of the high status have varied. Hunters, warriors, deep-rooted families, priests, knights. The West has considered the status and financial success increasingly equal since 1776 (Botton, 2005). However, in some societies, educational achievement has come to the forefront and at the same time, education has been seen as an important building block of the movement towards high status, an intergenerational bridge and a social status indicator (Mirowsky \& Ross, 2003). On the other hand, isn't there any elements that cannot be measured or are hardly measured but at the same time give the individual a certain status? This issue should still be noted as an important question to be answered. Professions with financial gains and high status are important, but it would be wrong to say that there is a one-to-one relationship between financial gains and high-status professions and status, and it can be seen that there is no real correspondence in some societies.

Teachers have a professional respect but every teacher may not be respected at the same level. In this case, differences that cannot complete each other between the status and the individual may arise; and the status and the individual who holds this status may not match. For this reason, it would be more proper not to establish a connection between the status and character structure of the individual (Ceylan, 2011).

Botton says that advantages of the high status are very delighting and high status brings money, freedom, and comfort but he also emphasized the feelings that have at least such importance: Being cared by others, being treated as a valuable person, being applauded and being flattered (Botton, 2005). From this viewpoint, when they enter the world of sports; alone and embarrassed people get off the ground (Filiz, 2002), have a sense of belonging to the society and gain a "place", in other words status, in the society by being applauded and appreciated for their success in sports. In a survey of young people, it was found that the most important criteria for determining the status of a girl was "being a leader in a sports activity" and the most important criteria for determining the status of a boy was "being a good athlete" (Chase \& Dummer, 1992). This result shows that sport is an indicator of status gain.

In addition to this status, the individual also holds more statuses and plays more than one role at the same time in the context of complex relations within the society. A public institution employee's also being a referee in national or international football competitions can also be given as an example. The individual has more than one status in social life by both working in a public institution and being a referee but he/she is identified by their prominent status and this indicates his/her referee profession and this brings the social perception of the sports into the forefront.

\section{SPORTS AND SOCIAL ASPECT OF SPORTS}

Sports is a socializing, physically developing, competitive and cultural phenomenon that individuals do individually or professionally as a leisure or a full-time profession with or without equipment within certain rules and that develops abilities of the individuals that are gained while they are turning their natural environment to human environment.

There is common belief that sports props development of the individual; because sports accepts true goodness and brings innocence to those who do it (Coakley, 2011). Sport is an important tool that helps individuals to keep living healthfully and develop both physically and psychosocially. In addition to the development of the individual, sports has a great importance in providing social peace 
and union. Providing social union will also provide development socially, culturally and economically.

Human is a social being and socializing is a formation affected by many complicated factors. In one sense socialization of an individual means individual's learning his own culture and other cultures related to that culture. In another sense socialization means individual's learning to obey the rules and values of the group and accepting the system of the values. This learning continues throughout the whole life and plays an important role in individual's interaction with the people around and all other environmental phenomenon.

Even though binding environmental phenomenon and social interactions form the basis of the humanity, there might be a conflict with different aims in group life or social relationships (Cheng et al. 2014). These conflicts decrease substantially in sports and the aim is to increase sociocultural and economic life, raise healthy generations, provide and sustain national unity by making society physically, mentally and spiritually healthy. There are many benefits of sports that is not only an aim for health and happiness of the individual and society, it is also a tool for it.

Physically, sports brings individuals agility, balance, strength, speed, condition, and esthetics. Spiritually, sports brings gains such as competition spirit, cooperation sense, working discipline, courage, self-esteem, competition ambition, acceptance of victory and defeat. In other words, sports is an inseparable part of raising of social people. Socializing through sports can provide humane coalescence by profitless intimacy (Gezer, 2014). Because, sports is a social phenomenon that contains strong physical endeavors or activities in the form of organized competition in which personal physical abilities are used mutually and relations are limited by various factors and it has taken an important social role in the society (MEB, 2012).

Sports is the way to get away from difficulties in daily life, the stress of urban life, developing technology and the worries. Another aspect of this choice is the idea of being healthy and social. Apart from socialization and being healthy, sports keeps young people away from bad habits and crime (Ramazanoğlu et al., 2005). In the United States, children are encouraged to enroll in sports activities. Studies show that sports activities are positively associated with reduced criminal behavior and increased academic and social performance (Kremer-Sadlik \& Kim, 2007).

Because sports appeal to the human, it is a very efficient and indispensable social phenomenon whether the goal is to create a healthy society with a high level of productivity or to be a constructive, healthy and productive youth that can look to the future with confidence or whether it is a tool that can be used against social dissolution and alienation. (Yetim, 2005). In both individual and team sports activities, individuals acquire many characteristics such as sharing pleasure and sadness of sportive encounters, belonging to a group and the representing the group in the sports activities (Yıldırım ve Özcan, 2011).

\subsection{Sports as Status Determiner}

In the dictionary meanings of social status, there is a general definition of position, dignity, and posture of the people in society. The social status is generally determined by social conditions and values in the society and sports have an important place among these values. The ever-increasing value of sports also affects the status of sports and athletes in society.

Sports has strong integrative, connective and socializing aspects. The integration aspect of sports provides an important ground to apply equal democratic policies without making discrimination between poor, rich, black, white, religion, race and nation (Karahüseyinoğlu et al., 2005). This can change the gained status of the individuals. It is not individual's choice to born white or black, it is an "attributed" status and the individual will determine his/her "achieved" status.

Other important issue that individuals value is being a good athlete (Asher et.al. 1977). For example, Olympic Games which dates back to 776 B.C. was an important activity in Ancient Greece. While athletes' aim was to win Olympic Games and gain financial resources and privileges, city-states made their name by supporting them morally and financially. These sports activities were also a determinant 
for social union and art (Golden, 2008). Some rights that are provided to the athletes in our country can be given example for this phenomenon and status:

Approximately two million young people every year take two-stage, six exams in total to get into the university. However, there are some special young people that can enter universities without any examination. These young people are those who represented Turkey in national and international competitions and won gold, silver or bronze medals. They have the right to enter the department of the field in which they have a medal without any examination (SSPC, 2016).

Athletes and team players who rank among top three in Turkish National Team, World and Europe tournaments and international competitions can postpone their military service until they turn 38 . In addition, Turkish citizen amateur athletes, or their families in case they die, and amateur athletes, coaches, and trainers who have won Olympic or world championship are put on salary and athletes who had an outstanding success internationally gain "State Athlete" title and their success is protected legally (www.taf.org.tr, 2013).

For the appointment of the national athletes, those athletes who ranked among top three in Olympic Games and in any other international competitions or gained national athlete certification by representing our country at least ten times can apply for physical education teaching without any examinations if they meet the requirements to be a teacher.

Examples given above are only samples that show the status of athletes and the privileges provided to them and these conditions are valid in our country only. Value of sports as a social status increase day by day around the world.

\section{CONCLUSION}

Sport is a physical, mental and social event that is in the interest of the majority of society. Human life and sports are inseparable and sports is an important factor and in some way a treatment way for a healthy and happy life.

Sport is a social phenomenon as well as it is individual and it is also an important cultural factor that makes human groups a nation. Beside other ways and tools, sports and activities related to sports have had influence in the endurance of societies. Origins such us sports that are intimate and socializing has an important role for social solidarity. Besides this social role of sports, it also brings the people who do sports to the forefront.

Individuals who do sports are watched with interest by the society via the successes they gain and athletes are valuable in every society. Amateur athletes are also valuable alongside the athletes who present their country in the international field. While sports provides individual to integrate into social groups and society, it is also an important factor for determining their status and position. For this reason, taking the socializing power and social prestige of the sports into consideration, it is considered that the habit of doing sports in childhood and making sports a living style contributes positively to the physical and psychosocial development of the individuals as well as social status.

"This work was presented as a verbal short presentation in the XIV. European Conference on Social and Behavioral Sciences Odessa, Ukraine August 23-26, 2017”.

\section{REFERENCES}

[1] Asher, S. R., Gottman, J. M., \& Oden, S. L. (1977). Children's friendships in school settings. Contemporary readings in child psychology/[compiled by] E. Mavis Hetherington, Ross D. Parke.

[2] Bilgin, N. (1991). Eşya ve insan. Ankara: Gündoğan Yayınları.

[3] Botton, A. Statü Endişesi. (2005). Çev. Ahu Sıla Bayer. İkinci Baskı. İstanbul: Sel Yayıncılık.

[4] Ceylan, T. (2011). "Toplumsal Sistem Analizinde Toplumsal Statü ve Rol/Social Status and Role in the Analysis of Social System", Atatürk Üniversitesi Sosyal Bilimler Enstitüsü Dergisi, 15(1).

[5] Chan, T. W. (Ed.). (2010). Social status and cultural consumption. Cambridge University Press.

[6] Chase, M. A., \& Dummer, G. M. (1992). "The role of sports as a social status determinant for children", Research quarterly for exercise and sport, 63(4), 418-424.

[7] Cheng, J. T., Tracy, J. L., \& Anderson, C. (Eds.). (2014). The psychology of social status (pp. 3-27). New York, NY: Springer. 
[8] Coakley, J. (2011). "Youth sports: What counts as positive development?", Journal of Sport and Social Issues, 35(3), 306-324.

[9] Coie, J. D., \& Kupersmidt, J. B. (1983). "A behavioral analysis of emerging social status in boys' groups", Child Development, 1400-1416.

[10] 1Demir, N. (2016). Birey,toplum,bilim:Sosyoloji temel kavramlar. Ankara: Turhan Kitabevi.

[11] Dodge, K. A. (1983). "Behavioral antecedents of peer social status", Child Development, Vol. 54,6. 13861399.

[12] Eder, D. (1985). The cycle of popularity: Interpersonal relations among female adolescents. Sociology of education, 154-165.

[13] Fichter, H.J. (2015). Sosyoloji nedir. Çev.Nilgün Çelebi. 2.Baskı. Ankara: Anı Yayıncılık.

[14] Gezer, H. (2014). Spor yapan ve spor yapmayan emniyet teşkilatı mensuplarının yaşam doyumu ve tükenmişlik düzeylerinin incelenmesi. Yüksek Lisans Tezi, Muğla: S1tk1 Kocaman Üniversitesi Sağlık Bilimleri Enstitüsü.

[15] Giddens, A. (2000). Sosyoloji. Haz.Hüseyin Özel,Cemal Güzel. Ankara: Ayraç Yayınevi.

[16] Golden, M. (2008). Greek sport and social status. University of Texas Press.

[17] Görücü, A. (2006). "Beden eğitimi ve spor yüksekokullarında okuyan öğrencilerin aktif spor yapma durumlarının belirlenmesi", Selçuk Üniversitesi Sosyal Bilimler Enstitüsü Dergisi, (16), 343-351.

[18] Hogan, D. P., \& Kitagawa, E. M. (1985). The impact of social status, family structure, and neighborhood on the fertility of black adolescents. American journal of Sociology, 90(4), 825-855.

[19] İlhan, L. (2008). "Eğitilebilir zihinsel engelli çocuklarda beden eğitimi ve sporun sosyalleşme düzeylerine etkisi", Kastamonu Eğitim Dergisi, 16(1), 315-324.

[20] Kalaycıŏlu, S., Çelik, K., Çelen, Ü., \& Türkyılmaz, S. (2010). Temsili bir örneklemde sosyo-ekonomik statü (SES) ölçüm aracı geliştirilmesi: Ankara kent merkezi örneği. Sosyoloji Araştırmaları Dergisi, 13(1).

[21] Karahüseyinoğlu, M. F., Ramazanoğlu, F., Nacar, E., Savucu, Y., Ramazanoğlu, M. O., \& Altungül, O. (2005). "Türkiye'nin spordaki konumunun bazı Avrupa ülkeleri ile karşılaştırılması", Doğu Anadolu Araştırmaları Dergisi, 3(3), 75-82.

[22] Karayaka, B. (2006). Sosyal tabakalaşma kuramlarının Türkiye’deki sosyo-ekonomik statü bölümlendirme çalışmalarıyla etkileşimi. Doktora Tezi, İstanbul: Marmara Üniversitesi Sosyal Bilimler Enstitüsü.

[23] Kerbo, H. R. (1983). Social stratification and inequality. New York: McGraw-Hill.

[24] Kremer-Sadlik, T., \& Kim, J. L. (2007). "Lessons from sports: Children's socialization to values through family interaction during sports activities", Discourse \& Society, 18(1), 35-52.

[25] Lembet, Z. (2014). Dergi reklamlarında sosyal statü göstergesi olarak markaların sunumu, Doktora Tezi, İzmir: Ege Üniversitesi Sosyal Bilimler Enstitüsü.

[26] Linton, R. (1936). The study of man. New York: Appleton Century Company, Inc. Lundberg, George, A., et.al. (1963). Sociology. New York: University of Washington.

[27] MEB. (2012). Spor sosyolojisi. Ankara: Milli Eğitim Bakanlığı Yayınları.

[28] Mirowsky, J., \& Ross, C. E. (2003). Education, social status, and health. Transaction Publishers.

[29] Odabaş1, Y. (2006). Tüketim kültürüyle yetinen toplumdan tüketen topluma. İkinci Bask1. İstanbul: Sistem Yayınc1lik.

[30] Parsons, T. (1970). Equality and inequality in modern society, or social stratification revisited. Sociological Inquiry, 40(2), 13-72.

[31] Ramazanoğlu, F., Karahüseyinoğlu, M., Demirel, E., Ramazanoğlu, M. ve Altungül, O. (2005). Sporun toplumsal boyutlarının değerlendirilmesi. Fırat Üniversitesi Doğu Anadolu Bölgesi Araştırmaları Dergisi, 3(3), 153-157.

[32] Sencer, M. (1967). "Sosyal sınıf kriterleri üzerine eleştirmeli bir deneme", Ayrı Baskı, İstanbul: Edebiyat Fakültesi Sosyoloji Dergisi, s.10.

[33] Şimşek, F. (2010). Yaşam tarzı haberciliğinin gelişimi ve statü oluşumuna etkileri. Yüksek Lisans Tezi, Konya: Selçuk Üniversitesi Sosyal Bilimler Enstitüsü.

[34] Turner, B.S. Statü. (2000). Çev.Kemal İnal. Birinci Baskı. Ankara: Doruk Yayınları.

[35] Vaillancourt, T., \& Hymel, S. (2006). Aggression and social status: The moderating roles of sex and peervalued characteristics. Aggressive Behavior, 32(4), 396-408.

[36] Yetim, A. (2005). Sosyoloji ve spor. Ankara: Morpa Yayınları.

[37] Yıldırım, S., \& Özcan, G. (2011). "Lisanslı olarak takım sporu ve bireysel spor yapan ile spor yapmayan ortaöğretim öğrencilerinin sosyal beceri düzeylerinin karşılaştırılması", Abant İzet Baysal Üniversitesi Sosyal Bilimler Enstitüsü Dergisi, 2,(23). 
[38] Zencirkıran, M. (2015). Sosyoloji. Bursa: Dora Basım Yayın Dă̆ıtım.

[39] http://www.osym.gov.tr/TR,2549/osysde-ozel-durumu-bulunan-adaylar.html Erişim Tarihi: 15.02.2017

[40] http://www.taf.org.tr/2013/12/04/basarili-sporculara-aylik-baglanmasi-ile-devlet-sporcusu-unvaniverilmesi-hakkinda-kanun Erişim Tarihi: 20.02.2017

[41] http://www.resmigazete.gov.tr/eskiler/2015/04/20150417-4.htm Erişim Tarihi: 21.02.2017

Citation: Hikmet TURKAY, A. Azmi YETIM. "The Relationship between Social Status and Sports" International Journal of Sports and Physical Education (IJSPE), vol 4, no. 1, 2018, pp. 7-13. doi:http://dx.doi.org/10.20431/2454-6380.0401003.

Copyright: (C) 2018 Authors. This is an open-access article distributed under the terms of the Creative Commons Attribution License, which permits unrestricted use, distribution, and reproduction in any medium, provided the original author and source are credited. 